\title{
Possibilities for Modifying the System of Proportional Representation Aimed at Stabilising the Executive in the ČR
}

\author{
Modelling the Results of the 1996 and 1998 Elections to the Chamber of Deputies*
}

TOMÁŠ LEBEDA ${ }^{* *}$

Faculty of the Social Sciences, Charles University, Prague

\begin{abstract}
Due to the longstanding situation in which the Czech Republic has experienced a series of unstable minority governments, serious debate has arisen over the need for changes to be introduced into the electoral system. This paper attempts to find a suitable alternative of the representational system, one capable of ushering in a period of government stability, by modelling the results of the elections held in 1996 and 1998. The aim is to determine which type of proportional electoral system could transform the party system in such a manner so as to render it capable of setting up a "monochromatic" or two-party majority coalition government. The method of modelling the election results is rooted in an exact calculation of specific election results by applying particular mathematical formulas to examples of various sizes of electoral constituencies. This paper reaches three possible solutions, one of which appears to be exceptionally effective. A number of options have been worked out in the paper whereby on the basis of the implementation of the proposed electoral system, the system of political parties in the Czech Republic could be reconstructed. A description and brief evaluation of the proposal for changing the electoral system made by the two largest political parties in January 2000, which is also grounded in making modifications to the representational system, is adjoined to the overall treatise as an actual addendum.
\end{abstract}

Czech Sociological Review, 2000, Vol. 8 (No. 1: 49-67)

It is now the third year since the regular parliamentary elections were held in the spring of 1996 and the Czech Republic still lacks a stable majority government. The elections issued in a two-year period of instability in the executive, during which time two minority governments alternated in power. The unorthodox steps leading up to the emergence of the second, Tošovský government, including the manner in which the legislative term was shortened, and the ensuing call for early elections are worth noting. The example of the two subsequent minority governments demonstrates vividly the number of problems tied to the instability of the executive in the young Czech democracy. Even the elections of 1998 failed to solve the situation and bring about a majority government. Though at first glance the results seemed promising, they were unable to ensure the establishment of a stable executive for the next four-year period. The outcome instead led to another unorthodox move - the signing of an "opposition agreement" and the consequent emergence of the third minority government in a row.

\footnotetext{
*) This paper stems from two more detailed papers published in Czech: "Vládní stabilita v České republice a volební systém poměrného zastoupení" [Lebeda 1998], and "Vládní stabilita v České republice a volební systém poměrného zastoupení II" [Lebeda 1999a].

**) Direct of all correspondence to Tomáš Lebeda, Karla Čapka 1, 36001 Karlovy Vary, e-mail lebeda.tom@seznam.cz
} 
In the midst of such a situation, serious discussion emerged over the possible need for changes to be introduced into the electoral system, and even for an overall revision of the constitution. The two largest parties, ČSSD and ODS, set up a commission to look into possible changes that could be introduced into the electoral system, the resulting provisions being intended to lead above all to ensuring the stabilisation of the executive branch of power. The ideal situation would be one in which following the elections no difficulties would be posed in setting up a homogeneous and efficient government, one which would command majority support in the lower chamber of Parliament and maintain strong, long-term perspectives for its continuing ability to function. The most frequent, though perhaps only the most vocal, opinion on this situation voiced by critics of the current electoral system calls for the transformation of the present proportional electoral system into a majority system. There are, however, many other alternatives. This paper aims at investigating other possible solutions that could remove the inadequacies of the current system while maintaining the principle of proportional representation. Specifically, I will attempt to deal with the question as to whether the existing principle of proportion applied to elections into the lower chamber of Parliament could be modified in such a way as to guarantee its ability to ensure a long-term environment conducive to the production of a stable executive. If in conclusion we reach a positive answer to this question, this answer will in fact be offering us one of the few possibilities, if not the only one, by which the existing situation could be treated without interfering with the constitution. ${ }^{1}$

\section{The Present Electoral System and its Influence on the Party System in the Czech Republic}

The existing system of elections into the lower chamber of Parliament in the Czech Republic is founded on the principle of proportional representation. The voter has one vote, which is cast on the regional candidate list of the chosen party ballot. This is a "closed" candidate list, but the voter is able to change the order of the candidates through four preferential votes. The distribution of parliamentary mandates takes place through two scrutinies, in which participate only those parties for which the election results on a statewide level exceed the 5\% threshold, or quorum, of valid votes (which is higher for coalitions at $7 \%$ for a two-party coalition, $9 \%$ for a three-party coalition, and $11 \%$ for a multiparty coalition). In the first scrutiny, the mandates are distributed on the level of the electoral districts with the use of the Hagenbach-Bischoff formula. ${ }^{2}$ The electoral districts are divided according to the old, territorial break-up of administrative units, i.e. seven regions and the capital city of Prague, which was in effect up until the beginning of the year 2000. The regions do not have a permanently allotted number of mandates, as these are distrib-

1) The requirement of the proportional principle in elections to the Chamber of Deputies is stated in the Constitution of the Czech Republic, article 18, item 2.

${ }^{2}$ ) The number of mandates can be determined from the number of votes in various ways with the use of mathematical election formulas. One of these is the Hagenbach-Bischoff formula. It belongs among those methods known as the methods of electoral quotients. These formulas work with an overall number of cast votes $(V)$ and the number of mandates to be distributed $(M)$ in order to determine from this the number of votes cast per mandate. The result is the electoral quotient $(Q)$. The division of mandates in practice appears as such, that the party receives that number of mandates corresponding to the number of times the electoral quotient can be divided by the number of votes that the party gained. A model of the quotient of the Hagenbach-Bischoff formula appears as $Q=V /(M+1)$ [see Grofman and Lijphart 1986: 112-123, Filip 1992]. 
uted according to election participation on the basis of the republic mandate quota, which is worked out through use of the Hare formula. ${ }^{3}$ On average, 25 mandates fall to one region, while in both of the last elections, in 1996 and 1998, the smallest - the Jihočeský region - obtained 14 mandates, and the largest - the Jihomoravský region - obtained 41. The party votes remaining from the first scrutiny are carried over into the second scrutiny, which encompasses the territory of the entire country. At that point the remaining votes from the regions are counted up for the individual parties, and the mandates are then further distributed, again through the use of the Hagenbach-Bischoff formula. The number of mandates allocated corresponds to the number that could not be distributed during the first scrutiny on the regional level. If even after the first calculation of the second scrutiny not all the mandates in the chamber (200) have been distributed, the remaining mandates are allocated in a second calculation to those parties demonstrating the largest remainder. In the second scrutiny, mandates are allocated according to the candidate lists that the parties compose after the first scrutiny has been completed, thus at the time when the regional results are already known.

This is how we could briefly characterise the main points of the existing electoral system. The manner in which it is conceived, using the $5 \%$ threshold, serves to block smaller parties from ever gaining entry into Parliament. However, this system does ensure those parties that manage to receive the minimum $5 \%$ of the national vote required to gain parliamentary representation a relatively large degree of proportionality. The $5 \%$ threshold ought to fulfil the function of a stabiliser, to prevent the powers in Parliament from splintering, and in this way to facilitate setting up government coalitions. As it works at present, however, it only preserves the established situation. Given this fact it cannot be considered as an element conducive to the consolidation of parliamentary power.

I see the causes behind the impossibility of setting up a majority government coalition as being based in two facts. First, within the Chamber of Deputies there are a few extremist parties with no, or very limited, coalition potential. The extremists considerably narrow the manoeuvring space of the democratic parties for forming majority coalitions. Second, the political spectrum is quite polarised even among the democratic parties, which again only complicates coalition negotiations. The Czech Republic is, in my opinion, a considerably homogeneous society. There is practically only one fundamental social fission that can be found in the country. However, there are at least four relevant democratic political parties. The existence of a greater number of parties struggling to win the support of similarly oriented voters (a phenomenon especially true on the right) leads to a situation of constant attacks and assaults being levelled among these parties themselves. This type of conflict is usually stronger than the natural rivalry existing between parties situated at opposite poles of the political spectrum, which in this case would involve the left. This kind of mutual antagonism peaked after the early elections of 1998 , when the two right-wing parties and the one middle-right party were unable to reach a coalition agreement even though between them they held a majority of 102 seats in the chamber of 200 seats.

The solution to both problems mentioned above could be to strengthen the majority effect of the electoral system. The appropriate variant of a proportional system with a

3) The Hare formula is an original electoral quotient formula, and also the most simple one. The model of the formula is $Q=V / M$. 
majority effect could render it possible to significantly suppress the influence of extremist political parties. Moreover, the party system would then be able to reform itself to take on a more efficient shape. The principle of proportional representation is generally quite variable, as it accommodates particular conditions and requirements. This variability stems from several changeable parameters inherent to it, the forces of which can, in certain combinations, mutually intensify, subdue, overlap, or remain entirely independent of each another. Of particular concern here is the size of the electoral constituency, the mathematical formula used to translate the percentage of votes cast into seats, the existence of a quorum and its level, and finally the number of scrutinies used, which to a large degree is connected with the type of mathematical formula employed. Of course, these are not the only factors, but in the case of the Czech Republic they are the most material ones. In this article I will attempt to find the form of proportional system that would usher in a stable executive by means of modelling the election results. Specifically, I will model the results from the 1996 and 1998 elections to the Chamber of Deputies of the Parliament of the Czech Republic.

At the outset it is first necessary to define precisely what is intended by the expression "modelling the election results". Simply put, it involves the exact calculation of the results of specific elections by using the various possible methods that can be applied in a proportional electoral system. In order to model the results it is necessary to make use of various mathematical formulas that are applied to certain possible size variants of electoral constituencies. In this way I have calculated the results of the 1996 and $1998^{4}$ elections to the Chamber of Deputies, in each case using the 66 possible methods as exactly as if I were genuinely calculating the election results. The model calculations were carried out gradually on four different size variants of electoral constituencies, including calculations carried out within the framework of a single constituency composed of the entire territory of the Republic, and calculations carried out in the framework of the eight former administrative (electoral) districts representing electoral constituencies up until the end of 1999. Other variants of constituencies used here include the 14 Supreme Territorial Administrative Units (VÚSC) which took over from the former administrative districts in the year 2000, and 38 small electoral constituencies that were created specifically for the task set forth in this article. These small constituencies were formed by dividing up individual districts in order to make them as equal as possible in size. Nine mathematical formulas were used to translate the percentage of votes cast into seats, and in the case of three formulas involving multiple scrutinies, additional possible formulas were applied in the second scrutiny. This work produced a rich amount of material useful for reaching more general conclusions.

For the purpose of this article I will introduce only those calculations carried out with the help of three formulas: the Hagenbach-Bischoff formula, which is currently used for elections into the Chamber of Deputies in the Czech Republic, the d'Hondt system, and the Imperiali system of highest averages. In the results of the formulas I have tested the latter two demonstrate the strongest potential for providing the executive with stability. ${ }^{5}$

4) Prior to the publication of this article models for the 1992 elections into the Czech National Council were also prepared, and confirmed the majority of trends and phenomena presented here.

${ }^{5}$ ) The Hagenbach-Bischoff formula has already been described above. The d'Hondt System divides in the sequence 1, 2, 3, 4, . and the Imperiali System - divides in the sequence of whole 


\section{Modelling the 1996 Election Results into the Chamber of Deputies}

After the elections in 1996, six political parties were voted into the Chamber of Deputies. The other ten running parties were unable to receive enough support to pass over the $5 \%$ threshold. From left to right on the political spectrum the successful parliamentary parties were: the Communist Party (KSČM) with 22 mandates, the Czech Social Democratic Party (ČSSD) with 61 mandates, the Christian Democratic Union-Czechoslovak People's Party (KDU-ČSL) with 18 mandates, the Civic Democratic Party (ODS), which won the elections with 68 mandates, the Civic Democratic Alliance (ODA), the smallest party, with 13 mandates, and the Assembly for the Republic-Republican Party of Czechoslovakia (SPR-RSČ) with 18 mandates. Extremist parties, left-wing Communists, and the extreme right-wing Republicans, none of which could be considered for inclusion in any coalition, won 40 seats together, which constitutes a full $20 \%$ of all seats. Those democratic parties wishing to form a majority coalition government would have needed to find support from a minimum of 101 out of the 160 democratic representatives. In this situation the only variant available for forming a majority coalition was the "grand coalition" of ODS and ČSSD. But this coalition was unacceptable for many reasons and would have been, in my opinion, an exceptionally bad move as parliamentary opposition would have then be composed primarily of extremist party representatives (40 deputies from extremist parties and only 31 deputies from the democratic parties of KDU-ČSL and ODA). Such a situation could in turn have had a future influence on strengthening the position of the extremists. In the end, the minority, centre-right government of Prime Minister Václav Klaus was formed, composed of ODS, KDU-ČSL and ODA, with a narrow minority of 99 deputies.

The following tables represent only a sample of the most important election calculations modelled for the task of this article. In particular, I will focus on those modelled calculations that demonstrate potential for ensuring the establishment of a majority government coalition. Most of the comments on the issue of electoral constituencies, such as individual calculations, forming a majority etc., will be left until the 1998 elections are modelled. The modelled calculations for the 1996 elections are presented here only briefly, and I have completely omitted the modelled calculations carried out within the framework of the previously mentioned single electoral constituency, as well as those for the eight electoral constituencies of the former, now non-existent, districts.

Table 1. 1996 elections: 14 electoral districts, "Supreme Territorial Administrative Units" (VÚSC)

\begin{tabular}{|c|c|c|c|c|c|c|c|}
\hline Syster & strength ratio & ODS & ČSSD & KSČM & $\begin{array}{l}\text { KDU- } \\
\text { ČSL }\end{array}$ & $\begin{array}{l}\text { SPR- } \\
\text { RSČ }\end{array}$ & ODA \\
\hline ischoff formula & 98:61:41 & 69 & 61 & 23 & 17 & 18 & 12 \\
\hline d'Hondt system & $98: 65: 37$ & 72 & 65 & 20 & 15 & 17 & 11 \\
\hline Imperiali system & $103: 73: 24$ & 87 & 73 & 17 & 12 & 7 & 4 \\
\hline 1996 regular results & $99: 61: 40$ & 68 & 61 & 22 & 18 & 18 & 13 \\
\hline
\end{tabular}

numbers beginning with two: $2,3,4,5, \ldots$ The mentioned electoral systems are described in [Lijphart 1986, Filip 1992]. 
The electoral constituencies in the modelled calculations above represent the newly valid electoral districts now in use. For the purpose of clarity, and so as not to be confused with the eight older districts, we will refer to the new districts by the acronym of their full title - VÚSC. The second column in the Table presents the ratio of strength in the Chamber of Deputies (e.g. 99:61:40). The first number in the ratio indicates the number of coalitiongovernment seats in Parliament, the second number indicates the seats held by opposition democratic parties possessing coalition potential, and the third number indicates the number of seats held by opposition, extremist parties with no coalition potential. In actual terms the ratio expresses the following proportional composition: "OSD + KDU-ČSL + ODA : ČSSD : KSČM + SPR-RSČ.

The calculation on the second-last row involves the Imperiali system, which is the only one that here enabled the formation of a majority government. A majority of 103 deputies is by no means great, but the strength of the extremist parties has been almost halved (from the original 40 down to 24). The application of the Imperiali system to VÚSC represents, in my opinion, one alternative for changing the electoral system. But I will say more about this variant when we reach the modelling of the 1998 elections.

Table 2. 1996 elections, 38 electoral constituencies

\begin{tabular}{lcrrrrrr} 
& & & & & KDU- & SPR- \\
System/Formula & strength ratio & ODS & ČSSD & KSČM & ČSL & RSČ & ODA \\
\hline Hagenbach-Bischoff formula & $101: 64: 41$ & 69 & 61 & 20 & 17 & 15 & 12 \\
d'Hondt system & $100: 77: 23$ & 89 & 77 & 17 & 10 & 6 & 1 \\
Imperiali system & $112: 85: 3$ & 106 & 85 & 3 & 6 & 0 & 0 \\
1996 regular results & $99: 61: 40$ & 68 & 61 & 22 & 18 & 18 & 13
\end{tabular}

The table above presents the use of small, on average five-mandate electoral constituencies. A noticeable majority effect appeared again under the Imperiali system. Not only would the coalition acquire a majority of 112 mandates, but the majority government could be formed by ODS alone with 106 deputies. The strength of the extremists has in this case been paralysed, with the presence of only three Communist deputies. This result is balanced with the serious losses felt by the two smallest democratic parties, KDU-ČSL (6 mandates) and ODA (no mandates). However, there still exists a very real possibility whereby these parties could gain representation in Parliament, which will be discussed later in connection with the modelling of the 1998 elections, and again finally in the conclusions. The Imperiali system as applied to small electoral constituencies thus offers another serious alternative that could provide the Czech Republic with an environment conducive to stable majority governments. The d'Hondt system, which is usually considered to benefit large parties, did not manage to provide the sought after majority government in the modelling of the 1996 elections in any of the variants for electoral constituencies.

\section{Modelling the Results of the 1998 Elections}

In the autumn of 1997, the minority coalition government of Václav Klaus collapsed under interesting circumstances: it occurred not due to external, opposition pressure, but rather due to pressure from within the coalition itself. There followed another minority government formed by Josef Tošovský, with the intention of carrying the country through to the early elections in the spring. These elections partially altered the appearance of the 
Chamber of Deputies, in which at that time only five parties maintained their representation. The Communist Party (KSČM) received 24 mandates, while the Social Democrats (ČSSD) won the elections and received 74 mandates. The People's Party (KDU-ČSL) won 20 mandates and the Civic Democrats (ODS) won 63. A new party, the right-wing Freedom Union (US) which emerged out of the split-up of ODS after the collapse of its coalition government in autumn 1997, appeared in the chamber with 19 deputies. This party de facto filled in the position in the chamber of ODA, which did not run in these elections. Unlike ODA, which lay to the right of ODS on the political spectrum, US eventually situated itself slightly more toward the political centre, after its later co-operation with the centrist KDU-ČSL in the Senate elections. In addition to seven other parties, the Republicans (SPR-RSČ) were unable to reach the threshold in these elections.

ČSSD won the elections but still had no hope of setting up a majority government. The anticipated coalition with the centrist (or centre-right) KDU-ČSL was not enough to provide the required number of deputies. The Freedom Union, which through its participation in the coalition could have ensured a majority government, refused to co-operate with the left-wing ČSSD, for reasons that are on the whole understandable. The dubious coalition of Communists and Social Democrats would also not have been able to attain majority support. The coalition of Communists, Social Democrats and the People's Party was ruled out beforehand by the People's Party itself. Conversely, a majority could have been attained through the centre-right coalition of ODS, KDU-ČSL, and US with 102 deputies. This was the only possible majority coalition, and the most unified in terms of programme and ideology, but attempts at its formation were not successful. This was due to an inability to reach a consensus among the parties involved, the source of the conflict of course stemming from the collapse of the similarly formed Klaus government, and further exacerbated over the course of the pre-election campaign by personal conflicts between the leading representatives of the parties.

Below I will attempt to present in a detailed manner the modelled calculations of the 1998 elections. The search for possible variants of majority coalitions in this case will not be as easy as in the previous, 1996 elections. Here it is necessary to use three strength ratios corresponding to the three possible alternatives for government coalitions. As I have pointed out, leaving aside the "grand coalition", the first variant appears as the centre-right coalition (ODS, US, KDU-ČSL) with 102 deputies, and the strength ratio for this coalition will also be presented first. The second variant to be presented involves cooperation between the victorious ČSSD and the third largest party - the Communists. This is a dubious arrangement and I would have strong reservations against any such cooperation, but prior to the elections voices from the ranks of ČSSD emerged in favour of maintaining this option, and for this reason it cannot be overlooked. Co-operation between ČSSD and KSČM can only be expressed here in a strength ratio of two positions: the number of mandates of the governing parties to the number of mandates of the opposition parties. The third variant, which could be considered as the optimal one, is that of co-operation between ČSSD and KDU-ČSL. This type of variant was declared as generally acceptable even prior to the elections, but in the end it did not succeed because the People's Party was unwilling to enter into any minority government dependent on the tacit support of the Communists. 


\section{Electoral Constituencies - VÚSC}

Table 3 offers a comparison of the division of mandates among the individual electoral constituencies of VÚSC. The calculation was carried out on the basis of the participation of the electorate and the application of the currently valid Hare formula and the method of greatest remainders.

Table 3. Fourteen electoral constituencies - VÚSC - division of mandates among individual constituencies

electoral constituency no. of mandates 1996 no. of mandates 1998 increase/decrease 1998

\begin{tabular}{lrrr}
\hline Praha & 23 & 24 & +1 \\
Central Bohemia region & 22 & 22 & 0 \\
České Budějovice region & 12 & 12 & 0 \\
Plzeň region & 11 & 11 & 0 \\
Karlovy Vary region & 5 & 5 & 0 \\
Ústí nad Labem region & 15 & 15 & 0 \\
Liberec region & 8 & 8 & 0 \\
Hradec Králové region & 11 & 11 & 0 \\
Pardubice region & 10 & 10 & 0 \\
Jihlava region & 11 & 11 & -1 \\
Brno region & 23 & 22 & 0 \\
Zlín region & 12 & 12 & 0 \\
Olomouc region & 13 & 13 & 0 \\
Ostrava region & 24 & 24 & 14.3 \\
ratio - smallest/largest & $1: 4.8$ & $1: 4.8$ &
\end{tabular}

The differences in the number of the allocated mandates between the years 1996 and 1998 are minimal. Changes occurred in only two of the fourteen constituencies (percentage of change $-14.3 \%$ ) and in neither case did it involve more than a single mandate. The ratio between the smallest and largest constituencies in 1996 (1:4.8) remained unchanged in 1998. However, this ratio is in no way ideal. Large constituencies produce relatively proportional results. But a number of smaller constituencies (especially the Karlovy Vary district) are capable of producing results similar to those seen in majority electoral systems. Even though similar examples of such a situation can be found elsewhere in Europe, this type of disproportion could be used as an argument against using VÚSC as electoral constituencies.

Table 4. 1998 elections - 14 electoral constituencies - "Supreme Territorial Administrative Units" (VÚSC) - valid administrative divisions as of the year 2000)

\begin{tabular}{|c|c|c|c|c|c|c|c|c|}
\hline \multirow[b]{2}{*}{$\begin{array}{l}\text { possible coalitions } \rightarrow \\
\text { system/formula }\end{array}$} & \multicolumn{3}{|c|}{ strength ratio in $\mathrm{CD}$} & \multicolumn{5}{|c|}{ number of mandates } \\
\hline & $\begin{aligned} & \text { ČSSD } \\
&+\mathrm{KSČM}\end{aligned}$ & $\begin{array}{c}\text { ČSSD } \\
+ \text { KDU-ČSL }\end{array}$ & $\begin{array}{c}\text { ODS+US } \\
+ \text { KDU-ČSL }\end{array}$ & ČSSD & & KSČM & $\begin{array}{l}\text { KDU- } \\
\text { ČSL }\end{array}$ & \\
\hline Tagenhach-Bischoff formu & 98 & $94: 83 \cdot 23$ & $102: 75: 23$ & 75 & 64 & 23 & 19 & \\
\hline & & & & 79 & & 2 & 16 & \\
\hline Imper & 104:96 & 102: & $96: 88: 16$ & 88 & 75 & 16 & 4 & \\
\hline 1998 regular results & 98:102 & $94: 82: 24$ & $102: 74: 24$ & 74 & 63 & 24 & 20 & \\
\hline
\end{tabular}


The first row of the table is of primary interest. As I have said, the Hagenbach-Bischoff formula in combination with VÚSC has already become a valid component of the present electoral system. However, as is evident in the modelled outcome, it does not bring about any serious changes. Differences of practically the same sort can be found in the modelled calculations of the 1996 elections.

Table 5. Hagenbach-Bischoff formula applied to VÚSC in the 1996 and 1998 elections percentage of mandates allotted in the first scrutiny

\begin{tabular}{ccccc} 
& \multicolumn{2}{c}{$\begin{array}{c}\text { constituency with } \\
\text { the lowest percentage }\end{array}$} & 1998 & $\begin{array}{c}\text { constituency with } \\
\text { the lowest percentage }\end{array}$ \\
\hline VÚSC & 1996 & $40 \%$ & $90.5 \%$ & $60 \%$
\end{tabular}

The outcome in Table 5 is a result of the smaller number of mandates that the Hagenbach-Bischoff formula is capable of distributing in the first scrutiny when applied within the framework of VÚSC. This fact is logically due to the larger number of electoral constituencies. However, one serious drawback is the fact that in certain constituencies it manages in the first scrutiny to distribute only a small percentage of the mandates that the constituency has been allotted, a phenomenon typical in this situation for small constituencies. In the table, the Karlovy Vary district is an example of this: in the 1996 elections it received only 2 out of 5 mandates, a mere $40 \%$, and in the 1998 elections it received 3 of 5 mandates, or $60 \%$. The situation in which candidates from a given district receive only a small percentage of the mandates that have been allotted to the district is simply unacceptable. The Hagenbach-Bischoff formula is generally unsuitable for environments made up of small electoral constituencies, especially when the mandates are distributed among a larger number of parties. As some VÚSC may also be defined as small constituencies, the formula shows itself to be unsuitable even for the new form of electoral constituencies in the Czech Republic. This finding provides another fundamental argument in favour introducing changes into the current electoral law.

Returning now to Table 4, it is clear that the d'Hondt system did help the strongest party, ČSSD, but not to any great extent. This system would produce the only model of a minimal majority coalition composed of ČSSD and KSČM, with 101 deputies. The Imperiali system is an entirely separate matter, as it is the only method that managed to "stir up" the number of mandates of individual parties. This system strengthens the gains of the larger parties more considerably. When compared to the actual outcome of the elections, the change in the mandates of the individual parties appears as follows: ČSSD would gain the most with 14 mandates and ODS would also gain 12 mandates, while KSČM would lose 8 mandates, KDU-ČSL would lose 6 , and US would suffer the largest loss of 12 mandates. The question then arises as to why KDU-ČSL, which obtained less votes, lost fewer mandates than the larger party KSČM. The explanation is simple, in that the behaviour of this formula within the framework of VÚSC more closely resembles that of the majority electoral system. One of the traits of such a system is that a smaller party with a strong local rooting as a rule gains a larger number of mandates than a similar or larger party that has its voters scattered throughout the territory of the state. The situation of these two parties to a certain extent resembles this model. KDU-ČSL thus profits from its higher support in some regions of Bohemia and Moravia. 
If we scan the ratio of strength it becomes clear that two variants of majority coalition governments emerge at once. The first is the dubious coalition of ČSSD and KSČM, which would receive 104 mandates in the chamber. The second possibility is the coalition of ČSSD and KDU-ČSL, which would receive 102 mandates. This calculation clearly demonstrates the problematic situation faced by the Czech party system. In order for the strength ratio to shift in a relatively unobtrusive way and enable the formation of a majority coalition, a much more considerable shift must occur in the acquisition of mandates among the individual parties. It is necessary to employ methods that would bring about a great enough gain for the large party in a potential coalition so that it exceeds that which is lost by its small coalition partner. One positive aspect is that a decrease in mandates can also occur in the case of the extremist KSČM, which is a party with at best only limited coalition potential. In this way greater space is opened up in general for the formation of majority coalitions. A majority of 102 mandates is not large and does not arouse too much confidence in the aspects of this system. However, the calculation of the 1996 elections conceded a majority of 103 mandates even for the then coalition of ODS, KDUČSL and ODA. Given that the positive outcome confirms itself repeatedly I would rank, with minor reservations, the combination of the Imperiali system and VÚSC among the methods to be considered as an alternative to the current electoral system. It is the only formula capable of achieving such an outcome in the framework of VÚSC, or in other words, within the newly valid administrative arrangement, and in the search for suitable variants for the electoral system, even this fact could play a more significant role.

\section{Electoral Constituencies}

In this section I will work with the small electoral constituencies created for the task set forth in this article. The original idea behind the constituencies, which were to have on average 5 mandates each, involved the necessity of creating a round number of 40 mandates in total. It was possible to divide the Czech Republic into 38 small electoral constituencies under the following specific conditions: (1) The constituencies had to respect the borders of the districts so that no district would be a part of two or more electoral constituencies and (2) the constituencies had to respect the borders of VÚSC so that no constituency would rest on the territory of two or more VÚSC. In other words, constituencies were created by uniting districts within the framework of the VÚSC. It may actually be an advantage to respect territorial arrangements when organising and subsequently summarising elections.

Table 6. 38 electoral constituencies - sizes of the electoral constituencies

\begin{tabular}{lccc} 
electoral constituency & $\begin{array}{c}\text { no. of constituencies } \\
\text { in 1996 }\end{array}$ & $\begin{array}{c}\text { no. of constituencies } \\
\text { in 1998 }\end{array}$ & change in 1998 \\
\hline constituencies with 3 mandates & 2 & 2 & 0 \\
constituencies with 4 mandates & 4 & 5 & +1 \\
constituencies with 5 mandates & 18 & 16 & $-3 ;+1$ \\
constituencies with 6 mandates & 11 & 12 & $-1 ;+2$ \\
constituencies with 7 mandates & 2 & 2 & $-1 ;+1$ \\
constituencies with 8 mandates & 1 & 1 & $-1 ;+1$ \\
\hline ratio - smallest/largest & $1: 2.67$ & $1: 2.67$ & 15.8 \\
percentage of change & & & 6
\end{tabular}


Table 6 presents a comparison of the size of the small electoral constituencies in the elections of 1996 and 1998. In both cases the number of mandates were allocated to the individual constituencies on the basis of electoral participation (or the number of valid votes), determined by means of the Hare formula and the method of greatest remainders. Thus the same method was used as that by which the mandates are distributed according to the currently valid electoral law. The size of the electoral constituencies fluctuates between three to eight mandates, the most common being those with five or six mandates. There were only two constituencies with three mandates during both election years and they were the same ones on both occasions. There was only one constituency with eight mandates in both election years, but on each occasion a different one. These extremes are clearly exceptions caused by the complications mentioned in connection with respecting the district and the VÚSC borders. Of the total 38 electoral constituencies, a change occurred in the number of mandates in only six cases between the years 1996 and 1998. The ratio between the smallest and the largest electoral constituency (1:2.67 - in both years) is the most favourable in this case, when compared with the regions (1:2.93 - in both years) and the VÚSC (1:4.8 - in both years).

Table 7. 1998 elections -38 electoral constituencies

\begin{tabular}{|c|c|c|c|c|c|c|c|c|}
\hline \multirow{3}{*}{$\begin{array}{l}\text { possible coalitions } \rightarrow \\
\downarrow \text { system/formula }\end{array}$} & \multicolumn{3}{|c|}{ strength ratio in $\mathrm{CD}$} & \multicolumn{5}{|c|}{ number of mandates } \\
\hline & ČSSD & ČSSD & ODS+US & & & & KDU- & \\
\hline & +KSČM & $+\mathrm{KDU}-\mathrm{C} \mathrm{SL}$ & $+\mathrm{KDU}-\mathrm{C} \mathrm{SL}$ & ČSSD & ODS & KSČM & ČSL & US \\
\hline Hagenbach-Bischoff formul & $100: 100$ & $97: 83: 20$ & $100: 80: 20$ & 80 & 68 & 20 & 17 & 15 \\
\hline d'Ho & $111: 89$ & $100: 79: 21$ & $89: 90: 21$ & 90 & 74 & 21 & 10 & 5 \\
\hline Imperiali system & 110:90 & $113: 84: 3$ & $90: 107: 3$ & 107 & 84 & 3 & 6 & 0 \\
\hline 1998 regular results & $98: 102$ & $94: 82: 24$ & $102: 74: 24$ & 74 & 63 & 24 & 20 & 19 \\
\hline
\end{tabular}

Table 7 presents the modelled calculations carried out within the framework of the small constituencies. For small constituencies, the Hagenbach-Bischoff formula is simply unacceptable, regardless of any of the results. In the first scrutiny it was able to distribute a mere $68.5 \%$ of the mandates and in the modelling of the 1996 elections it managed only $58.5 \%$ of the mandates. The remainder had to be carried over into the second scrutiny. Furthermore, in the case of this system, extreme situations occurred again, whereby only one half of the allotted mandates were distributed within the constituency.

The d'Hondt system allowed for one majority alternative in the form of a coalition between ČSSD and KSC̆M. The Communists lost the least in comparison to the actual results. Conversely the greatest loss was felt by US. A very similar trend was witnessed also in the modelling of the 1996 elections. Under these circumstances the d'Hondt system is not an acceptable alternative. It is, however, one of the most frequently used electoral formulas in systems of proportional representation around the world. This fact may make it much more preferable as opposed to the less known Imperiali system. Moreover, there is a way to possibly alter its continuously unsatisfactory outcome: to further reduce the size of the electoral constituencies. The modelled calculation was carried out on 38 small constituencies. The majority of them were allotted five or six mandates. If the number of electoral constituencies were increased toward 50, the constituencies would receive on average four mandates. In such a situation the d'Hondt system would produce entirely different results, closer to those seen in a majority system. This statement is demonstrated in the fact that with the modelled calculation for the year 1998, the Communists, as the 
largest of the smaller parties, gained only a quarter of the mandates in the fourth position of the order of allocating mandates within the constituencies. The remaining threequarters were allocated in the fifth and sixth positions. This means that the Communists in a four-mandate constituency gained considerably fewer mandates than in the modelled calculation, and the situation was similar in the case of the remaining smaller parties.

This is not all as simple as it seems. The creation of small electoral constituencies is complicated by the understandable necessity (and desirability) of respecting the borders of the districts. Moreover, I formed my 38 constituencies under the condition that the VUSC borders remain intact. If we were to free ourselves of this condition I believe that the number of electoral constituencies could yet be increased, and in this situation the d'Hondt system would become acceptable. However, there exist certain borders that ought not to be crossed, even if the size of the constituencies were to be reduced, and my assumption is that the 38 constituencies already lie on these borders.

The final but most important calculation carried out on the small constituencies involves the Imperiali system. As with VÚSC, in the case of the small constituencies it is the only alternative that offers more than one variant of a majority coalition. However, here the overall results are much more radical. The system unambiguously boosted the two largest parties. As compared to the actual results, ČSSD gained an additional 33 mandates, meaning they held an overall majority of 107 mandates. ODS gained an additional 21 mandates giving them a total of 84 . The other parties saw only a decrease, with KSČM losing 21 mandates and reaching a total low of 3, KDU-ČSL losing 14 and being left with 6, while US lost all 19 of its mandates. The Imperiali system confirmed for the second time, as with the modelling of the 1996 elections, that it is capable of producing a gain for the victorious political parties significant enough to make them capable of commanding majority support in Parliament. ${ }^{6}$ I consider the reduction in the number of mandates gained by KSCMM to only three, the same number it acquired in the modelling of the 1996 elections, to be a positive development. Given the strong local support in certain regions for KDU-ČSL, which has already been mentioned, the result for this party was higher than for KSČM even though the Communists overall received $2 \%$ more of the vote. Of particular interest is the comparison of the electoral constituencies in which KDU-ČSL and KSČM were successful in both years. It must be remembered that the two parties received in both subsequent elections the same number of mandates, KSČM three, and KDU-ČSL - six. The electoral gain of these parties in individual constituencies of course never exceeded one mandate. The Communists gained two to three mandates in 1998 in the same two constituencies as in 1996. KDU-CSL gained all six mandates in both election years also in the very same constituencies!

The Imperiali system in both years guaranteed the victorious political parties an absolute majority in the Chamber of Deputies, and this effect was confirmed by both parties. Following the 1996 elections, a majority government was set up by ODS, and after the 1998 elections, by ČSSD. This provides a view of a positive alternation of the two largest parties. Such an outcome could fully be achieved by the 38 small electoral constituencies we have mentioned, which respect the VÚSC borders. The organisation of the elections would in this way remain without any difficulty within the framework of exist-

${ }^{6}$ ) In the modelled 1996 elections ODS gained 106 mandates. The combination mentioned here thus confirmed itself in "both directions", in the case of ODS and in the case of ČSSD. For more see [Lebeda 1998]. 
ing administrative divisions. There is no doubt that this would be advantageous to the relevant bodies in charge of running the elections, as well as to the political parties themselves and their organisational structures. I consider the Imperiali system in combination with the small constituencies as another suitable variant for ensuring a stable executive in the Czech Republic.

To sum up, three possible variants have been determined as being capable of leading to the formation of a more stable and effective government commanding majority support in Parliament within the framework of the proportional electoral system. The first variant was the Imperiali system as applied to the 14 electoral constituencies corresponding to VÚSC, thus the newly valid criteria. The second possibility appeared with the d'Hondt system applied within the framework of 50 small, on average four-mandate electoral constituencies. The third and in my opinion most suitable variant showed itself to be the Imperiali system as applied to the 38 small, on average five-mandate constituencies. On the basis of an electoral system drawn up according to the third variant, a fundamental change in the appearance of the party system would also occur. My assumption is that there exist three possible means by which the party system could be reconstructed.

The first means of reconstructing the party system is clearly evident. The last modelled calculation allocated $95.5 \%$ of the seats in the Chamber of Deputies to the two largest parliamentary parties. This means an almost complete realisation of the idea of bipartism, or the two-party system. Parties as a rule would command majority support in the chamber, and would have more room to implement their programmes with fewer obstacles.

Alongside clear bipartism, this system opens the possibility of drawing some of the smaller parties into participation in the chamber. How is this possible? A proportional system with this kind of strong majority effect has one interesting characteristic: it significantly motivates parties into pre-election co-operation. At present only a few small parties have any motivation to form pre-election coalitions, and only out of concern about reaching the threshold and gaining representation in Parliament. However, in certain circumstances it may be an advantage even for a large party to engage in pre-election cooperation with a small party and enter the elections together. Even a small percentage increase in electoral gains, caused by the votes cast for the small coalition partner, leads to a considerable increase in the number of acquired mandates, which can be decisive for gaining a majority of seats in the chamber. Situations of this type can be modelled through motivational calculations.

As an example of a motivational calculation I can introduce the theoretical cooperation of ODS and US in the 1998 elections. I should first point out, however, that the motivational calculation is only a technical indicator, which is not intended to, and in fact cannot, predict what the genuine common gain of these two parties would be, as it leaves out many important factors such as the mutual relationship between the two parties at the time of the elections and the psychological impact of such co-operation on the voter. Nonetheless, it is possible to artificially create a situation, in which ODS and US would enter the elections as a single coalition, and in which we would use the recommended Imperiali system as applied to 38 small constituencies. The first row of Table 8 presents the modelled calculation of the Imperiali system (as it was depicted in Table 7), and the second row shows its motivational calculation. The "actual gain" (that is the difference between the results when both parties run separately and the results when they run to- 
gether) shows how much higher the theoretical gain for ODS and US would be as opposed to the situation in which each party runs alone. The motivational index shows the increase in the number of mandates in percentage points.

Table 8. 1998 elections - motivational calculation I - the Imperiali system + small electoral constituencies

\begin{tabular}{lccccccc} 
system/formula & CSSD & $\begin{array}{c}\text { ODS } \\
(+\mathrm{US})\end{array}$ & KSČM & $\begin{array}{c}\text { KDU- } \\
\text { ČSL }\end{array}$ & US & $\begin{array}{c}\text { actual motivational } \\
\text { gain }\end{array}$ & index \\
\hline $\begin{array}{l}\text { Imperiali system } \\
\begin{array}{l}\text { Imperiali - motivational } \\
\text { calculation ODS + US }\end{array}\end{array}$ & 107 & 84 & 3 & 6 & 0 & & \\
& 92 & 107 & 1 & 0 & $\mathrm{X}$ & 23 & $+27.4 \%$
\end{tabular}

By running alone, US would not gain any mandates, and ODS in the same situation would gain 84 (see the first row). However, the motivational calculation allocates a total of 107 mandates (see the second row) when they run together, a result that would theoretically alter the election victory. The remaining parties, with the exception of ČSSD, would practically disappear from the chamber altogether. I have already mentioned that this calculation cannot be considered as a serious statement of the actual situation were these two parties to genuinely run together, but it does suggest something. Generally we could say that the percentage increase of a small political party, which alone would not gain entry into the chamber, is potentially significant for the large party given the considerable hike in the common gain in mandates. In any case, this form of pre-election coalition is entirely dependent on the willingness of large parties to engage in such cooperation. Examples borrowed from the international political scene demonstrate that preelection party coalitions are usually stronger and more stable than government coalitions formed on the basis of election results. This development could even lead to the establishment of two strong blocks of alliances, which could alternate in power in a manner similar to that of two alternating parties. One example of a similar system that works due to the double-ballot majority electoral system may be found in the case of France. The second variant for reconstructing the Czech party system conforms to this description.

The third and final possibility presented here for a new form of party system could be the two-and-a-half party system. It is possible to assume that after reform initial tendencies would incline most strongly in this direction. My personal assumption, however, is that in the long run this trend is not the most likely. It presents a situation in which a political entity would wedge itself in between the two largest parties and also be large enough to be capable of overcoming the inherent barrier of the electoral system. This kind of party, or more probably a coalition of parties, would be present in the chamber in a considerably under-represented form, but by spreading its forces in a particular way it would be capable of tipping the proverbial balance, and thus become a participant essential to the formation of majority coalitions dependent on which of the two large parties the small one inclines toward. In the circumstances of the Czech Republic, an analogy for this could be found in the four-party coalition that emerged out of the Senate elections. This variant also has a relevant motivational calculation. 
Table 9. 1998 elections - motivational calculation II - the Imperiali system + small electoral constituencies

\begin{tabular}{|c|c|c|c|c|c|c|c|}
\hline system/ & ČSSD & ODS & KSČM & $\begin{array}{c}\text { KDU-ČSL } \\
(+\mathrm{US})\end{array}$ & US & $\begin{array}{c}\text { actual } \\
\text { gain }\end{array}$ & $\begin{array}{l}\text { motivational } \\
\text { index }\end{array}$ \\
\hline nper & 107 & 84 & 3 & 6 & 0 & & \\
\hline $\begin{array}{l}\text { mperi } \\
\text { alcula }\end{array}$ & & 75 & 1 & 25 & $\mathrm{X}$ & 19 & $+317 \%$ \\
\hline
\end{tabular}

As the table shows, the two small parties could defend themselves against the two-party system by entering into a pre-election coalition, the motivational calculation indeed indicates such a situation. The result of 6 mandates for KDU-ČSL and no mandates for US would in a joint running of the two parties be transformed into 25 mandates altogether. The actual gain would be 19 mandates, displayed in the percentage points of the motivational index at $316.7 \%$. In this particular case the role of a coalition partner essential to the formation of a majority government would genuinely be achieved. Even so I must again point out that these numbers are only for orientation, and in reality the situation could turn out quite differently. The motivational calculation is not an exact prognosis but rather a demonstrative indicator that serves to point out some of the more interesting properties of this kind of electoral system.

In connection with the previously mentioned specific example of co-operation between KDU-ČSL and US it is necessary to make the following remarks. The situations involved in elections to the Senate and elections to the Chamber of Deputies differ in many ways. The executive branch of power is established on the basis of elections to the lower chamber. For this reason a central political entity formed along the lines outlined above would need to be, in terms of its ideology and programme, more unified than is true in the case of elections to the upper chamber. It would require the establishment of a harmonic and dominant understanding concerning which of the large parties it would be willing to form a coalition government with. In the long run, this political entity would also need to be willing to enter into a coalition in either direction of the political spectrum. The question is whether or not small parties such as KDU-ČSL, US and perhaps other small right-wing parties would be capable of this. The distance in terms of ideology and programme between the Christian KDU-ČSL, with its strong rural orientation, and US, which to a great extent could be characterised as an urban liberal party, leads to some doubt in this area. Any conflict within such a political entity would be uncompromisingly penalised in the electoral system. Even a small percentage decrease could indicate a drastic loss for the "third" party of a large majority of their mandates in subsequent elections. Such a loss could only lead to their long-term and even - given the psychological impact of the electoral system - definitive exclusion from the parliamentary scene. However, the conditions for forming, as well as the general appearance of pre-election coalitions could be addressed through a specific electoral law. In the end it would solely depend on such a law as to whether or not in general any of the coalition alternatives mentioned here could be achieved.

\section{Conclusions}

On the basis of the modelling of the 1996 and the 1998 elections, the most suitable variant for changing the electoral system while preserving the principle of proportional representation appears to be the combination of the Imperiali system and the 38 small electoral 
constituencies with an average of roughly five mandates each. The result of its implementation would likely wipe out the extremist parties with limited coalition potential, and the electoral system would considerably strengthen the position of the large parties. Two alternatives emerged to enable the continuing survival of small parties in the lower chamber:

1) Close pre-election co operation with a large party sharing a similar ideology and programme, which would be a form of co-operation to some extent advantageous even for the large party. Given the strong motivational effect, even a slight percentage contribution from the small party would mean an increase in the overall number of mandates, which could in turn be decisive for establishing a parliamentary majority.

2) Close pre-election co-operation between small parties, which could lead to the creation of a strong and most likely centrist unit, capable of overcoming the barrier of the electoral system. In the lower chamber this political entity would most certainly be underrepresented, but by spreading its forces it could play a decisive role in determining the establishment of government coalitions. This variant would require a considerable degree of unity in the programme and outlook of the participating parties in order to ensure its long-term survival.

On the basis of what has been demonstrated here, the implementation of this electoral system could evolve in three directions. The first could lead to classic bipartism: two main political parties would alternate in power and a monochromatic government would be set up commanding majority support in the lower chamber, which would cause neither of the two parties any great difficulties. The second could direct the party system toward the creation of two blocks of strong alliances, which would alternate in power similarly to the first case. The third could lead to the emergence of the two-and-a-half party system, which would mean the existence of two parties, as in the first case, with the addition of one small, central political entity with the potential to tip the scales in one direction or another. This last variant, however, given the unforgiving nature of the electoral system, would demand exceptional homogeneity within the central unit, and given the character of the potential participants this seems a less likely in the long run. A collision within the central, political entity would again lead back to one of the first two variants.

In conclusion it is necessary to briefly recall some of the more important traits of the selected parameters of the electoral system. Small constituencies present the hope of enabling much closer contact between the voter and the deputy, both prior to elections and even during the legislative term when the mandate is held. Even with the considerably majority-like character of the electoral system, electoral lists would traditionally remain within the Czech system. At the same time, parties would be forced to choose a much larger number of strong and qualified personalities for the posts of leaders on their candidate lists. Preferential votes on small party lists could become an important route toward personalising the proportional system. The voter could in this way acquire a greater opportunity to influence the personal representation of the party. The character of the closed candidate list would in general not change much at all, unlike the situation given the present modification. However, it would be necessary to set a percentage of preferential votes necessary for moving a candidate into the lead.

The existence of the quorum could become unnecessary. Its use, preferably at the same level it is now set, could nonetheless guarantee even greater stability than that which is seen in the majority system. The absence of the quorum could lead to problems 
with extremism and with the emergence of obscure local and independent candidates. The extremists could concentrate most of their attention during the campaign on picking out electoral constituencies in which, on the basis of the composition of the electorate, they might expect success. Such a strategy of concentrated efforts could, however, be very successful for all parties. The 5\% threshold forces most parties to campaign and struggle over the entire area of the country. The majority effect of small constituencies and the Imperiali system would thus be safeguarded and intensified through its combination with the use of a quorum.

\section{Actual Addendum}

In the January 2000 agreement that deepened the "opposition agreement", ČSSD and ODS reached an understanding on the precise form of change to be introduced into the electoral system. This agreement emerged out of a compromise. Bear in mind that my study rests on an arrangement of 38 electoral constituencies and the Imperiali system for allocating mandates. The ODS proposal was quite similar - the Imperiali system and 3536 electoral constituencies. The two parties probably concurred on the number of constituencies, but ČSSD proposed the use of the d'Hondt system, which is applied more frequently and is less disproportional. The compromise then should be the use of the "modified d'Hondt" and 35 electoral constituencies.

The "modified d'Hondt" is a more or less artificially formed compromise. The modification resembles what is referred to in political science as the Sainte-Lague method. Its effects benefit small parties. In order to subdue this characteristic, a modified variant was determined, which raises the first divider from a value of 1 to a value of 1.42 . If we carry out the same change on the d'Hondt system, we reinforce its majority character and come closer to the effects of the Imperiali method, which was proposed by ODS. Thus more precise than a "modified d'Hondt" would be a "reinforced d'Hondt" system. The d'Hondt system altered in this way is of particular significance for the very small electoral constituencies of ordinarily five to six mandates. Given the increase of the first divider from 1 to 1.42, it very effectively prevents small parties from gaining the first mandate. At the same time, it continues to behave in the same way as the classic d'Hondt system to the party that gains the first mandate in the electoral constituency. I wrote that this variant was a compromise between the d'Hondt and Imperiali systems, but it is necessary to provide a more precise characterisation. In the small constituencies proposed by ČSSD and ODS (an average of 5.7 mandates per constituency) the properties of the d'Hondt system more closely approach the results of the Imperiali system. Conversely, if larger constituencies were to be set up, of roughly 10 mandates more, the results would approach or even compare with those of the classic d'Hondt system. Generally, however, the dividing line is dependent on other factors as well, particularly on the number of parties among which the mandates are allocated, the mutual proportions of electoral gains (votes), the level of the threshold if there is one, and the territorial break up of the support of the electorate. 
Table 10. 1998 elections - the proposal of ČSSD and ODS (the modified d'Hondt method and 35 electoral constituencies

\begin{tabular}{|c|c|c|c|c|c|c|c|}
\hline system/formula & ČSSD & ODS & KSČM & $\begin{array}{l}\text { KDU-ČSL } \\
\quad(+\mathrm{US})\end{array}$ & US & $\begin{array}{c}\text { actual } \\
\text { gain }\end{array}$ & $\begin{array}{l}\text { motivational } \\
\text { index }\end{array}$ \\
\hline $\begin{array}{l}\text { modified d'Hondt system } \\
\text { modified d'Hondt system } \\
\text { - motivational calculation }\end{array}$ & 102 & 86 & 4 & 7 & 1 & & \\
\hline KDU-ČSL + US & 93 & 71 & 2 & 34 & $\mathrm{X}$ & 26 & $+325 \%$ \\
\hline
\end{tabular}

If we calculate the possible election results according to the electoral system proposed by ČSSD and ODS, the Social Democrats would win with an absolute majority of 102 mandates, in front of ODS in second place, which would win 86 seats in the lower chamber. The Communists would have four mandates, the People's Party seven, and US only one. Theoretically the Social Democrats could easily set up a monochromatic majority government with strong support in the lower chamber and potential long-term stability. In practice, however, there would surely emerge some sort of pre-election co-operation between the smaller parties, such as that described in the conclusions to the study in this article. A motivational calculation based on a joint running of KDU-ČSL and US in the 1998 elections shows that the election results in this case would turn out entirely differently. The victorious ČSSD would win 93 mandates and ODS 71, while KDU-ČSL and US would together win 34 mandates, and KSČM would have only 2 mandates. I must again stress that the motivational calculation here is not a prediction of the mandate gains to be had in a joint candidature. Its task is to confirm the high degree of motivation of the parties (especially the small ones) toward pre-election co-operation, which could be a matter of their survival. At the same time it can tell us a great deal about the feasibility of pre-election co-operation between certain parties.

The variant of the election system proposed by ČSSD and ODS (the modified d'Hondt system +35 electoral constituencies) is so similar in character to the proposal in my study (the Imperiali system +38 electoral constituencies) that the aforementioned conclusions also apply. The only difference in contrast to the Imperiali system is that the modified d'Hondt system provides more space for a third political party. The party system in the Czech Republic could yet on the basis of the selected electoral system reconstruct itself according to the three possibilities that I have described here.

Translated by Robin Cassling

TOMÁŠ LEBEDA has completed the Bachelor's level of study in the field of the humanities at the Pedagogical Faculty, UJEP in Ústi nad Labem. He is currently in the Magister level of study in the field of political science in the Faculty of Social Sciences at Charles University in Prague. His interests focus on the issues of electoral systems and their influence on the constitution of party systems, particularly concentrating on the specifics involved in the system of proportional representation. To date he has published his work in the Politologický časopis (1998 and 1999) and in a collection of papers stemming from a conference, the Possibilities for Change and Reform of the Election System in the Czech Republic (1999).

\section{References}

Filip, Jan 1992. Základní otázky volebního práva v ČSFR [Fundamental Questions on Electoral Law in CSFR]. Brno: Masaryk University, Faculty of Law. 
Grofman, Bernard, Arend Lijphart (eds.) 1986. Electoral Laws and Their Political Consequences. New York: Agathon Press.

Lebeda, Tomáš 1998. "Vládní stabilita v České republice a volební systém poměrného zastoupení" [Government Stability in the Czech Republic and the Electoral System of Proportional Representation]. Politologický časopis.

Lebeda, Tomáš 1999a. "Vládní stabilita v České republice a volební systém poměrného zastoupení II." [Government Stability in the Czech Republic and the Electoral System of Proportional Representation II]. Politologický časopis.

Lijphart, Arend 1986. "Degrees of Proportionality of Proportional Representation Formulas." Pp. 112-123 in Electoral Laws and Their Political Consequences, ed. by B. Grofman and A. Lijphart. New York, Agathon Press. 